\title{
Ensaio, ignorância, desobramento: um espaço titubeante entre aula e cena
}

Essay, ignorance, unwork: a faltering space between class and scene

Juliana Jardim ${ }^{1}$ 


\section{Resumo}

O artigo integra investigação de pós-doutorado que tem como eixo os temas ensaio, ignorância e desobramento, na composição de um espaço entre aula e cena. A ideia de um entre tornase fundamental para um ensaio filosófico que quer pensar o encontro ao redor de textos. O espaço referido situa-se entre prática e pensamento, e pretende ser delineado pelo texto do artigo que procura mover-se entre seus temas. Estabelecemos paralelismos talvez improváveis, ao aliarmos o par Joseph Jacotot e Jacques Rancière aos gestos ensaísticos de Michel de Montaigne, em seu espaço originário de composição, além de outras ligações, a fim de pensar uma ideia de encontro entre aula e cena que ative a possibilidade de alguma inoperosidade.

Palavras-chave: Aula; cena; ensaio; ignorância; desobramento

\section{Abstract}

The paper stems from a postdoctoral research, which hinges upon the issues of essay, ignorance and unwork, to make up a space between class and scene. The idea of a between becomes paramount for a philosophical essay which aims to consider the encounter amidst texts. The aforementioned space is found between practice and thought and shall be defined throughout the paper, with a view to moving among its subject matters. Parallels, maybe unlikely ones, are drawn by joining the pair Joseph Jacotot and Jacques Rancière to Michel de Montaigne's essaylike gestures, in his original compositional space, in addition to other connections, to think of the idea of encounter between class and scene, which triggers the possibility of some inoperativeness.

Keywords: Class; scene; essay; ignorance; unwork 
Como um cão

diz Cézanne

assim o pintor deve

olhar, com o olho

still \& fast

desviado

W.G. Sebald e Jan Peter Tripp, O não-contado

O presente ensaio integra uma pesquisa de pós-doutorado ${ }^{2}$ que por sua vez nasceu da necessidade de adensar o pensamento acerca de temas que vinham - e seguem - sendo experimentados no projeto artístico Ensaios ignorantes; antes dele, na Peça aos poucos, e ainda em pesquisas anteriores, desenvolvidas entre espaços de cena e aula, entre prática de criação cênica e pedagogia. Este artigo tem origem em um incômodo situado entre espectador, homem de teatro, pesquisador e professor, que surge na crise com o corpo que esquece o espaço de cena e o espaço de aula, ambos entendidos como espaços de obra, operação, trabalho, ação, urgência, mas que compreenderiam, sempre, os seus contrários, a saber, a desobra, a inoperância, a ociosidade, a inação, a lassidão. A palavra désoeuvrement significa inação, ociosidade, e contém em si a palavra oeuvre, obra. O désoeuvrement - desobramento - fala de "alguma passividade, evoca uma lassidão e até talvez um tédio. Contraponto da obra, entendida como dialética do trabalho diurno, o désoeuvrement não poderia ser apenas sua oposição simétrica, assim como a morte se opõe à vida" (Pelbart, 1989, p.80).

Dito de maneira mais explícita, queremos experimentar uma composição textual ensaística que possa - na linha do exposto pelo filósofo alemão Theodor Adorno sobre o ensaio como forma literária - meditar, ela mesma, um corpo mais titubeante entre cena e aula, talvez nem cena, nem aula, sem, com isso, pretender "construir nenhum andaime ou estrutura" (Adorno, 2003, p.31). Pretendemos sustentar a indefinição de um espaço, permitindo-nos silenciar as tentativas de responder às perguntas sobre suas definições. A ideia é tentar compor um entre - limitado, margeado pelas alianças que fazemos e pelo que se escreve entre elas -, vocábulo presente desde nosso título e repetido intensamente ao longo do artigo. A palavra entre na língua portuguesa está situada na categoria de preposição e propomos que ela seja tratada também como substantivo, ocupando as duas categorias.

Tudo se passa entre nós. O entre - e aqui seguimos Jean-Luc Nancy - "não tem nem consistência própria, nem continuidade. Ele não conduz de um ao outro, ele não faz tecido, nem cimento, nem ponte. Talvez nem seja justo falar em 'vínculo' sobre ele: não é nem ligado, nem desligado, mas está aquém, ou melhor, é o que está no coração de um vínculo, o entrecruzamento de filamentos no qual as extremidades restam separadas até em sua atadura" (Nancy, 2013, p. 23) ${ }^{3}$. O entre é a distensão e

\footnotetext{
2 Este texto é oriundo da pesquisa de pós-doutorado Ensaio, ignorância, desobramento: uma prática intervalar entre a aula e a cena, com supervisão do Prof. Dr. Júlio Groppa, na FEUSP, entre 2013 e 2016, da qual também fez parte, entre março e dezembro de 2014, o Estágio de Pesquisa do Exterior Paisagens errantes entre a aula e a cena: Incêndios e Fernand Deligny, supervisonada pelo Prof. Dr. Fernando Bárcena Orbe, na Universidade Complutense de Madrid, ambas financiadas pela FAPESP. Durante o estágio, a pesquisadora realizou estância na torre de Michel de Montaigne, em Saint Michel de Montaigne, na França, em agosto de 2014. As opiniões, hipóteses e conclusões ou recomendações expressas neste material são de responsabilidade do autor e não necessariamente refletem a visão da FAPESP.

3 “Cet 'entre', comme son nom l'indique, n'a ni consistance propre, ni continuité. II ne conduit pas de l'un à l'autre, il ne fait pas tissue, ni ciment, ni pont. Peut-être.
} 
a distância abertas pelo singular enquanto tal, e como seu espaçamento de sentido: "O que não se mantém ligado, sustentado à distância do 'entre' não é nada além de imanência desmoronada em si, e privada de sentido" (Nancy, 2013, p.23) ${ }^{4}$.

$\mathrm{Na}$ conferência "assinatura acontecimento contexto", Jacques Derrida afirma que lidar com o escrito é lidar com o ausente. Com a ausência de destinatário e com a ausência do emissor, do destinador, "para que um escrito seja um escrito, é necessário que continue a 'agir' e a ser legível mesmo se o que se chama o autor do escrito não responde já pelo que escreveu" (Derrida, 1991, p.356). Nunca teremos, como afirma ainda Derrida, "o conjunto das presenças que organizam o momento da inscrição do escrito". Se retornamos ao início de sua conferência, podemos afirmar então que, para ele, comunicação não é o veículo, o transporte ou o lugar de passagem de um sentido e de um sentido uno. Não há um sentido, nem uma passagem, há um livro e "tudo está no livro" (Rancière, 2007, p.40). Há que suportar, ao menos um pouco, essa afirmação.

Nos dias atuais, textos ainda são tratados em aula e em cena a partir de algum querer dizer. Esse querer dizer refere-se a duas instâncias: busca-se saber e transmitir (a alunos e público) o que o autor ou o texto quiseram dizer ou o que todos os intérpretes dizem quando se põem a pensar no que o autor ou o texto dizem. Textos são interpretados. A outra instância do querer dizer diz respeito àquilo que professor ou encenação querem dizer por meio dos textos que usam em aula e cena. Interpreta-se com textos. O diretor teatral inglês Peter Brook insiste na existência de

\begin{abstract}
um grande mal-entendido que bloqueia muito o trabalho no teatro. Consiste em acreditarmos que aquilo que o autor escreveu no papel é uma forma. [...] Tudo o que sabemos é que o autor escreveu uma cadeia de palavras que têm a possibilidade de originar formas incessantemente renovadas. Não há limites às formas virtuais que existem num texto. [...] Uma vez impressa, há a forma que é o livro. [...] Mas o que foi escrito e impresso não tem ainda a forma do que um dia poderá sair dessas palavras. Se dizemos 'estas palavras devem ser pronunciadas de determinada maneira, ter uma determinada cor, uma música...', infelizmente, ou talvez felizmente, enganamo-nos sempre. Isso leva-nos ao que há de pior na tradição, no mau sentido da palavra. Somos constantemente surpreendidos pela quantidade de formas inesperadas que podem surgir dos mesmos elementos e a tendência humana para as recusar representa sempre a redução de um universo (Brook, 1993, p.68).
\end{abstract}

Movidos por pistas e por uma lógica de investigação acerca de estudos de texto teatral presentes no filme Ricardo III, um ensaio, dirigido por Al Pacino, idealizamos e dirigimos a Peça aos poucos: experiências de repouso sobre o texto Timon de Atenas, de William Shakespeare, que realizou 25 experiências públicas em 2008/9, com parceiros diversos, nas cinco macro regiões da cidade de São Paulo ${ }^{5}$. As experiências públicas de aproximação ao texto referido no título desejavam que todo aprender, todo

\footnotetext{
même n'est-il pas juste de parler de 'lien' à son sujet: il n'est ni lié, ni délié, en deçà des deux, ou bien, c'est ce qui est au coeur d'un lien, l'entrecroisement des brins dont les extrémités restent séparées jusque dans leur nouage." (Tradução nossa).

4 "Ce qui ne se tient pas à distance d"entre' n'est rien qu'immanence effondrée en soi, et privée de sens." (Tradução nossa)

5 Aldeia indígena Tenondé Porã, Cia. Teatral Ueinzz, Associação Cultural Paideia, CAC-ECA-USP - com Prof. Flávio Desgranges e alunos da disciplina Jogos Teatrais -, Programa Vocacional, Oficina Cultural Oswald de Andrade, Projeto Quixote (UNIFESP), Universidade São Judas Tadeu, Centro Cultural Rio Verde..
} 
pensar e todo fazer agir do texto fossem realizados entre equipe e público, por meio de ações cênicas ensaísticas. Da Peça aos poucos surgiram os Ensaios ignorantes, projeto que tem como eixo o livro $O$ mestre ignorante: cinco lições sobre a emancipação intelectual, de Jacques Rancière, além de conexões com a lógica ensaística literária, teatral e fílmica. Trabalhamos com ensaios privados em torno do livro-eixo já citado, entre 2010 e 2011, e desde então realizamos também apresentações, às quais nomeamos ensaios públicos. O livro-eixo é o gerador de nossos modos de estar em cena com o e em público e é matéria decisiva para nossa opção em nos mantermos como um ajuntamento: não somos um grupo de teatro. Também propusemos que esse livro dialogasse com Ensinamento universal. Língua materna, de Joseph Jacotot, autor do método biografado por Rancière em $O$ mestre ignorante.

Em linhas gerais, os Ensaios ignorantes caracterizam-se por encontros de longa duração - de 3 a 6 horas - que acontecem perto de um material textual, seja ele um livro, um roteiro ou um libreto, em torno do qual realizamos ações cênicas, nomeadas repousos e derivas. Alguns exemplos de formatos de Ensaios ignorantes já realizados foram as ações de repouso e deriva com o livro $O$ mestre ignorante: cinco lições sobre emancipação intelectual, de Jacques Rancière, em 2011, no Centro Cultural São Paulo; a leitura pública coletiva do livro De segunda a um ano, de John Cage, com ensaios musicais e com o ensaio cênico de sua Conferência sobre o compromisso, no Centro Cultural São Paulo, em 2012. Em ocupação realizada no SESC Interlagos, em 2012, realizamos três formatos distintos dos Ensaios ignorantes. O primeiro deles, Ensaio: solidão, realizou-se no palco italiano e compunha-se por um roteiro de textos sobre aprender na solidão, tendo como interlúdios diversos trechos de $O$ mestre ignorante. O roteiro bilíngue foi lido pelo filósofo da educação Jorge Larrosa, espanhol, e pela autora do presente artigo, junto a breves intervenções do núcleo de participantes dos Ensaios ignorantes, entre palco e plateia, com a participação do músico Thomas Rohrer, que realizava intervenções sonoras. Antes do último terço do Ensaio: solidão, um vídeo do solo de dança Como superar o grande cansaço?, de Eduardo Fukushima, foi exibido numa tela. Nada do que se deu no Ensaio: solidão foi ensaiado previamente. O segundo ensaio dessa ocupação em Interlagos, o Ensaio da Experiência, constituiu-se por uma leitura integral de Da experiência, de Michel de Montaigne, entre ensaístas e público, em um viveiro de plantas. O terceiro modo formal de ensaiar, nessa etapa, deu-se nos Ensaios para adultos de uma Opereta ignorante para crianças, constituídos por roteiro cênico em forma de libreto composto por derivas teatrais, musicais e textuais a partir dos temas ensaio e ignorância, entre Montaigne e o par Jacotot-Rancière. Em alguns momentos o público era convidado a entrar em cena para ensaiar a Opereta junto com os ensaístas. Ao longo de 2013, 0 ajuntamento de ensaístas criou e realizou publicamente os Ensaios ignorantes para crianças impossíveis. Com eixo na obra, em edição bilíngue, Contos para crianças impossíveis, de Jacques Prévert, a forma desses Ensaios, sempre em recomposição, consistia na leitura integral do livro por todos os presentes, entremeada por ações de deriva, preparadas pelo núcleo artístico, e digressões realizadas por todos, núcleo e público, a partir de regras determinadas pelos ensaístas. Esses são exemplos de formas dos Ensaios ignorantes já realizados publicamente. Mas outros eixos do trabalho serão mencionados, para delimitar o campo do presente artigo. 
Os Ensaios ignorantes públicos têm sido sempre mediados por regras, sendo que a primeira delas diz que qualquer pessoa pode entrar e sair do espaço quando quiser. Essa orientação existe pois somos, de um modo geral, acostumados a respeitar aquilo que está em cena como se fosse algo superior. Queremos, de certa forma, nos opor a esse hábito, por mais difícil que seja a tentativa. As regras não têm como objetivo dirigir de forma estrita as possibilidades de experiência do público e do núcleo artístico nos Ensaios. Exercitamos a organização e a divulgação de regras a fim de mover um campo de jogo e ação que dialogue com os temas concernentes ao projeto. E sabemos que elas não podem garantir a densidade ou a qualidade do encontro, nem suas características, mas confiamos que sua existência e partilha pública podem nos conduzir a espaços e ações menos diretivos. Os limites querem expandir o que se dá em cada ensaio. "Um quer falar, o outro quer adivinhar - eis tudo" (Rancière, 2007, p.94):

Não existem formas mais privilegiadas do que pontos de partida, cruzamentos e nós que nos permitem aprender qualquer coisa nova, mas, para isso, é preciso recusarmos, primeiramente, a distância radical, em segundo lugar, a distribuição dos papéis, e em terceiro lugar, as fronteiras entre os territórios. Não temos de transformar espectadores em atores e os ignorantes em experts. Nós temos que reconhecer o saber da obra no ignorante e a atividade própria do espectador (Rancière, 2012, p.26).

A partilha pública do material textual dos Ensaios deseja justamente dar a ler o texto que nos move a gerar nossas novas escrituras (cênicas, musicais, textuais etc.), assim como abrir para digressões das pessoas do público e dar voz a seus pensamentos. O espaço dos Ensaios é ocupado tanto por ensaístas quanto pelo público, sem distinção de lugares. São espaços preparados com um mobiliário diverso de assentos individualizados: sofás, bancos, tapetes, almofadas, dispostos de forma a não gerar relação palco-plateia espacialmente separada; nunca se esboça a disposição de uma roda. A organização do espaço almeja alguma hospitalidade para o público, a possibilidade de que os presentes realizem algum tipo de exposição sutil e a preservação dos cantos como espaços de solidão, ainda que dentro de um local com muitas pessoas. Não privilegiamos focos, recortes nem alguma exposição indesejada dos envolvidos. Quem quer ver, vê, quem quer sair, sai. Todos podem mudar de lugar quando quiserem. Não somos tontos: sabemos que o público, ao chegar, espera algo que venha de nós, dos ensaístas, dos artistas. As regras querem operar com esses temas, jogar com eles. Todos podem ler. Nosso trabalho não dialoga com as formas de leitura encenada (onde o texto é lido apenas pelos intérpretes) ou com alguma ideia de boa leitura restrita apenas a quem tem algum contato mais cotidiano com o ato de fazer soar um texto em voz alta: atores, bons leitores. A sustentação da leitura do livro é regra para todos os ensaístas e para o público. Experimentamos possibilidades em que a leitura é tomada (quem deseja ler, toma a palavra) e também, em que ela é doada (quem lê interrompe a leitura e espera que alguém continue). O texto sempre soa em voz alta. O projeto não serve para incentivar leitura nem formar leitores, mas realiza ações cênicas com a presença do texto para experimentar, em diálogo com Jacotot/Rancière, abolir as distâncias. Não queremos explicar nada, por isso, 
nunca realizamos debate. Entre os integrantes da equipe, nunca conversamos sobre nenhum livro de trabalho, mas, ao contrário, buscamos inventar regras para fazer coisas com eles. As digressões cênicas podem dar conta do querer-dizer das pessoas presentes. Nunca houve nem haverá especialista a fim de explicar coisas ao público, pois também não queremos nos tornar especialistas em nossos textos de trabalho. Os especialistas que se aproximaram dos Ensaios são sempre convidados a se ensaiar em outros terrenos, a estar em cena, a fim de tentar não incorrer nos gestos explicativos e informativos.

Nesse sentido, para marcar o caráter não totalizador do gesto ensaístico, recorremos, uma vez mais, ao filósofo Adorno:

O ensaio reflete o que é amado e odiado, em vez de conceber o espírito como uma criação a partir do nada, segundo o modelo de uma irrestrita moral do trabalho. Felicidade e jogo lhe são essenciais. Ele não começa com Adão e Eva, mas com aquilo sobre o que deseja falar: diz o que a respeito lhe ocorre e termina onde sente ter chegado ao fim, não onde mais nada resta a dizer: ocupa, desse modo, um lugar entre os despropósitos (Adorno, 2003, p.16).

Buscamos estabelecer alianças entre referências teóricas distantes entre si no tempo, para que elas possam, de algum modo, penetrar os poros e fazer ventar algo outro, que sequer se sabe o que é. Pretende-se fazer ressoar a noção de desobramento (désoeuvrement), de inoperosidade, já mencionada, permeada pelo que temos nomeado gesto ensaístico, entre aspectos das infinitas possibilidades do ensaio teatral e do ensaio literário. Mas nossas alianças dizem também respeito aos ecos das acepções da palavra ignorância, conforme tratada nos escritos de Joseph Jacotot e de Jacques Rancière, quando o segundo escreve sobre e por sobre o primeiro, parafraseando-o. A palavra espaço enraíza-se na simples acepção de lugar ocupado e desocupado entre limites, contaminada pelos sentidos de proximidade e distância (portanto, de presença e ausência) e afasta-se sutilmente das acepções oriundas dos campos da geografia e da cenografia teatral, ou ainda das artes visuais e cênicas, de modo geral. Queremos propor outro percurso para espaço, um tanto aterrado no solo dos temas que traçamos. Por isso, visitamos Michel de Montaigne. Porque é no pequeno, no detalhe, em um corpo só, em um homem só, que as coisas acontecem. Um homem que para, suspende, decide, age, limita, inventa, colhe coisas, monta um espaço, uma mochila, uma pasta, o porta-malas de um carro, a torre de um castelo. Um homem que quer ter algum prazer, alguma alegria de viver, algum contato, quer tornar-se outra coisa, ter um orgasmo, umedecer-se, emagrecer, comer, beber, cuidar, esfregar-se com outros, ficar só, e, para tanto, esse corpo age, decide, afirma, põe, recusa, espera. E são as coisas que esse homem põe juntas aquelas que ocupam algum espaço, que reverberam em alguém, chamam a fazer algo, celebram alguma coisa com outros corpos, com as palavras e com os silêncios entre elas. Uma visita a Montaigne talvez possa nos fazer pensar nossos próprios modos de agir e de não agir entre palavras e homens, entre o asilo e o convívio, entre aula e cena, já. Dessa maneira, ainda que desde outro contexto, podemos pensar de modo suspenso esse entre, conforme nos indica a reflexão de Adorno: 
É inerente à forma do ensaio sua própria relativização: ele precisa se estruturar como se pudesse, a qualquer momento, ser interrompido. O ensaio pensa em fragmentos, uma vez que a própria realidade é fragmentada; ele encontra sua unidade ao buscá-la através dessas fraturas, e não ao aplainar a realidade fraturada. [...] A descontinuidade é essencial ao ensaio (Adorno, 2003, p.35).

\section{Michel de Montaigne e seus ensaios pelo espaço: um homem do entre}

$\mathrm{Na}$ torre de Michel de Montaigne, em Saint Michel de Montaigne, comuna francesa na região da Dordonha, distante quase oitenta quilômetros da cidade de Bordeaux, a primeira frase que se lê sobre a porta do castelo do criador dos Ensaios pergunta: "Que sei eu?". Esta é somente a primeira das várias sentenças que podem ser lidas ao longo da caminhada, pois, já dentro da torre, mais precisamente em sua antiga biblioteca, outras frases aparecem. Qualificada por Montaigne como o lugar mais inútil da casa (Montaigne, 1984, p. 378), a biblioteca foi o espaço por ele escolhido para - em 21 de junho de 1571, aos 38 anos $^{6}$, retirando-se dos encargos públicos e distanciando-se da mãe, da esposa e daquela que seria sua única filha - passar "a maior parte dos dias da vida e a maior parte das horas do dia" e, ainda que de modo imprevisível, dar nascimento a essa escrita por ele nomeada como Essais, no original francês. Até então a palavra essai não tinha a acepção de ensaio, conforme conhecemos hoje. Essai significava somente tentativa.

Montaigne era um sagaz mediador, negociador entre o rei Henrique III e o futuro rei Henrique de Navarra, dentre outros. Vestia-se de protestante quando era católico, para acolher os protestantes em sua torre, que, vale lembrar, comportava uma capela católica no piso térreo. Ao mesmo tempo viajante e caseiro, a cavalo e no alto da torre, ora fazia a corte ora parecia seduzir-se a si mesmo. Retirou-se e começou a fazer um livro, mas parece que foi o livro que o fez - "sou eu mesmo a matéria desse livro" (Montaigne, 1984, p.95) ${ }^{7}$. Queria pintar-se a si mesmo, mas os Ensaios estão repletos de textos intrusos. Não tinha, em princípio, nenhum leitor como destinatário de sua escrita, e escrevia para si mesmo, mas Erich Auerbach considera-o criador de uma nova profissão e de uma nova categoria social: o leigo na condição de escritor, "o primeiro faiseur de livres [fazedor de livros] na acepção atual - nem poeta, nem erudito, mas autor de livros: escritor" (Auerbach, 2007, p.15). Michel de Montaigne era um homem do entre.

Montaigne ordenou que fossem pintadas nas vigas do teto de sua biblioteca, de formato circular, situada no segundo andar da torre, frases colhidas - direta e indiretamente - de autores latinos e gregos. As sentenças estão dispostas em direções opostas, em cada um dos três blocos de vigas paralelas. No terceiro deles, todas as frases, com exceção da última, estão escritas no sentido oposto ao que se pode ler no segundo e no primeiro blocos. Ou seja, para ler três das frases de cada bloco, a saber, todas ocupando as extremidades deles, é necessário também que se faça um 
giro, ao andar. As duas vigas restantes são perpendiculares às outras três e situam-se entre elas. Em cada uma dessas duas vigas, mais largas e compridas, há mais quatro sentenças escritas, somando, portanto, oito. Essa disposição dos textos obriga-nos a uma caminhada e a um giro. Só se pode ler as frases se andamos sob as vigas, curvando a cabeça para o teto. Montaigne caminhava, tirava livros das estantes, lia e ditava, a um secretário, os Ensaios, nascidos de anotações feitas nos livros, de citações - ora mais ora menos fiéis aos autores aos quais se refere -, de conversas, de seus distintos humores, de anedotas (Zweig, 1981) e das situações por ele vividas: "Qualquer retiro exige um espaço para passear; meus pensamentos cochilam se os deixo sentados; meu espírito não anda sozinho se as pernas não o agitam. Os que estudam sem livros são todos assim" (Montaigne, 1984, p.378).

"Andar, saltar e dar cambalhotas, para Montaigne era tudo uma coisa só: 'a pluma como os pés'. Palavra, pluma, pé" (Legros, s/d, p.2). Há extensa bibliografia sobre essa biblioteca e também sobre a invenção de um modo de escrita em Montaigne ${ }^{8}$. No último dos ensaios que escreveu, Da experiência, Montaigne se posiciona em relação aos livros, no ir e vir entre o que chama de "tratar de si mesmo" nos Ensaios e as leituras com as quais opera para escrevê-los:

Poremos fim algum dia a essa mania de interpretar? Teremos feito algum progresso no caminho da tranquilidade? [...] Interpretar as interpretações dá mais trabalho do que interpretar a própria coisa, mas escrevemos mais livros sobre livros do que sobre os assuntos mesmos; comentamo-nos uns aos outros. Há excesso de comentadores, mas escassez de autores. A principal ciência do século consiste em entender os sábios; não está nisso o fim último de nossos estudos? Nossas opiniões sustentam-se mutuamente, uma serve de degrau à outra e assim acontece que quem sobe mais alto e maior reputação adquire não tem em verdade grande mérito, pois não fez senão superar de um átimo o que vem logo abaixo (Montaigne, 1984, pp.478-485).

Lugar de meditação, do qual podia avistar todo o entorno, a torre de Montaigne guarda espaços ainda surpreendentes. No primeiro andar, que tem o chão sobre o teto do céu estrelado da capela, há o quarto de Montaigne, com duas aberturas nas paredes. A primeira delas é uma escada aberta ao andar térreo, que tinha o objetivo de fazer chegar o som das missas celebradas na capela. O formato de escada fazia com que o som atravessasse o ar com suavidade, permitindo que Montaigne, quando enfermo, pudesse escutar as vozes que vinham de baixo, sem ferir os ouvidos. Na outra abertura, situada muito próxima a uma das aberturas da parede que dá para fora da torre, protegida por tules oleosos - janelas não existiam - , havia uma cadeira. Ali Montaigne escondia-se, todas as vezes em que algum convidado indesejado buscava-o na torre. Sempre com os portões abertos, a disposição da propriedade permitia que qualquer um entrasse. Montaigne inventou esse esconderijo para se proteger dos indesejados e, ainda escondido, poder ler e escrever.

$\mathrm{Na}$ composição dos espaços que compunham a torre, interessa-nos lembrar outras três presenças intensas no delineamento do traçado gestual do ensaísta. Todo 
o impulso de escrita de Montaigne dá-se na perspectiva da morte, da solidão e da amizade. Além de se configurarem como temas-eixo de alguns ensaios, ocupam, em seu ir e vir temático, muitos dos ensaios como assuntos secundários, sem perder intensidade. A aparente contradição entre os temas da amizade e da solidão "se explica pelas relações do espírito com o espaço que se oferece a ele: o espaço está aberto para aquele que medita solitariamente; mas, para aquele que se mistura à multidão, o único espaço livre é interior" (Starobinski, 1992, p.106). Entre a expansão na solidão e o monólogo interior em plena multidão, germina o ensaísta.

Ler com a cabeça para baixo (nos livros) e para cima (no teto), caminhar, anotar, lembrar-se, apropriar-se, conversar, inventar, ditar: entre um retiro premeditado e um espaço cuidadosamente delineado, ainda que sem a intencionalidade da escrita, nasce o gesto ensaístico.

\section{Palavras e sentidos para este espaço}

Ao nos aproximarmos de Montaigne para compor nossa acepção de espaço, propomos delimitar esta noção como um entre, perceptível intangível - quase um oxímoro -, impossível de ser tocado concretamente, mas, muitas vezes, visível para os sentidos. Espaço que é vão, vazio, lugar a ser ocupado ou não. Temos nos orientado por uma bússola cuja agulha encontra-se margeada pelas palavras tentativa e hipótese. Tentativa, aqui, considera-se método. Hipótese é a condição inerente a essa escrita, possível também de ser composta pelo leitor, no giro imprevisível que pode fazer a agulha, desde que ele a ponha em marcha, mirando-a.

Há encontros, palavra substantiva. E há isso que se chama a "sensação de um encontro", expressão adjetiva, que qualifica positivamente um encontro qualquer. Por encontro compreendemos a copresença entre pessoas e pessoas ou entre pessoas e coisas. Sobre a "sensação de um encontro", façamos uma distinção temática, pois no campo teatral fala-se muito sobre ela. O diretor teatral inglês Peter Brook, ao tratar o tema, nomeia-o com a impressão de um "abraço" entre cena e público (Brook, 1993, p.96). A expressão toma características de gosto duvidoso, retirada de seu contexto e da totalidade das palavras do diretor, porém nos serve para especificar nosso campo. Não pretendemos adjetivar nenhuma ideia de encontro.

Nossa hipótese considera que existem textos e existem pessoas que se põem a trabalhar com textos, entre gestos de repouso e deriva, segundo nossa nomenclatura. A palavra repouso refere-se a esses gestos de todos nós quando tentamos estar próximos de um texto, lendo-o, escutando-o, manipulando-o, operando-o, recebendo-o, sem sair dele, sem buscar outros textos sobre ele. Walter Benjamin nos fala aqui:

A força da estrada do campo é uma se alguém anda por ela, outra se a sobrevoa de aeroplano. Assim é também a força de um texto, uma se alguém o lê, outra se o transcreve. Quem voa vê apenas como a estrada se insinua através da paisagem, e, para ele, ela se desenrola segundo as mesmas leis que o terreno em torno. Somente quem anda pela estrada experimenta algo de seu domínio e de como, daquela mesma região que, para o que voa, é apenas a planície desenrolada, ela faz sair, a seu comando, a cada uma de suas voltas, distâncias, belvederes, clareiras, perspectivas, assim como o chamado do comandante faz sair soldados de uma fila. Assim comanda unicamente o texto copiado a alma daquele que está ocupado 
com ele, enquanto o mero leitor nunca fica conhecendo as novas perspectivas de seu interior, tais como as abre o texto, essa estrada através da floresta virgem interior que sempre volta a adensar-se: porque o leitor obedece ao movimento de seu eu no livre reino aéreo do devaneio, enquanto o copiador o faz ser comandado. A arte chinesa de copiar livros foi, portanto, a incomparável garantia de cultura literária, e a cópia, uma chave para os enigmas da China (Benjamin, 2011, p.15).

Repousar significa um certo copiar, como acabamos de fazer, andar pelo texto e não somente sobrevoá-lo de aeroplano, ou seja, aquiescer mediante o comando do texto que nos ocupa.

A palavra deriva, conforme pretendemos delimitar, refere-se aos gestos de saída do texto, que se dão em digressões de pensamento, de escrita, de fazer agir o texto de modos distintos. Acontece, muitas vezes, a partir de algum repouso, durante ou depois de uma aproximação. Trata-se de uma situação mirada como ideal, um ponto de chegada que geraria um modo de partida. Aquilo que, na maior parte das vezes, nas rotinas de aula e de criação teatral costuma ser categorizado como erro, falha, desconcentração, perda, queremos delinear como parte integrante das práticas com textos. Continuamos a pensar a forma do ensaio "fascinado pelo olhar fixo daquilo que é confessadamente derivado" (Adorno, 2003, p.28). Os gestos vividos em solidão quando lemos - fechar as páginas, subir, baixar ou fechar os olhos - passam a conviver nos encontros coletivos ao redor de textos.

Nossa hipótese pensa e quer fazer pensar algum encontro de pessoas com textos que não se situe nem na cena e nem na aula, mas está imaginado como instalação titubeante justamente em um intervalo, em uma pausa, em um espaço entre o que se nomeia aula e o que se nomeia cena. Essa instalação deve pendular nesse entre.

Sigamos nessa obsessão para pensar gestos de repouso e deriva com textos, ensaiando alguma filosofia do encontro que tem como eixo fazer convergir e divergir esses campos de pensamento. A tentativa de experimentar e de instalar a tal hipótese faz parte de uma investigação em curso também fora dele, há alguns anos ${ }^{9}$.

Não estamos inaugurando a ideia de aula e cena conectadas em um mesmo espaço, ainda que este que propomos seja, por ora, inconfigurável. No espaço do começo do teatro que se inscreve na história do Brasil (Prado, 2012) estava uma relação estrita e direta entre a aula e a cena. O teatro catequético no Brasil deu nascimento simultâneo a alguma cena e a alguma aula. O chamado aspecto não-institucional da educação jesuítica no Brasil durou aproximadamente dois séculos e meio e era uma pedagogia por exemplos, vivencial, realizada fora do espaço da escola. Em nossos primórdios, no ciclo em que criação cênica e aula coincidiam, a meta era ensinar. Mais: o espaço entre cena e aula deveria, para a Companhia de Jesus, obter sucesso em produzir, no aluno-atuante, uma outra alma, diferente da sua mesma, porém similar àquela do mestre, figura composta por gestos de um professor multidisciplinar, de um mentor espiritual, de um diretor e dramaturgo teatrais, apenas para mencionar a complexidade de funções presentes na figura do catequizador. A produção dessa

9 Tanto nas etapas práticas das pesquisas referidas na nota 1 quanto nos projetos artísticos citados, e também em pesquisa de doutorado (Jardim, 2009). 
nova alma fundamentava-se no violento apagamento de uma memória anterior, no delineamento dessa alma que perdia sua singularidade para se tornar europeia, por meio daquilo que se ensinava e também, justamente, por responsabilidade dos específicos meios usados para se ensinar aquilo que se ensinava (Hansen, 2006). De que modo? Escrevia-se textos de naturezas distintas, imitando os gêneros europeus, misturava-se línguas com extrema habilidade (tupi, português, espanhol, guarani), operava-se com esses textos a partir de uma fusão entre a retórica antiga e a teologia-política escolástica e juntos, catequistas e índios, punham-se a fazer teatro. Portanto, ensaiar uma ação e um pensamento que localizam aula e cena em um mesmo espaço - do modo como vimos delineando aqui - pode ser também um modo de recompor essa origem, retraçar a história, talvez, a partir de outra poética e de outra ética.

\section{Joseph Jacotot e uma absurda ignorância: outro homem do entre}

Exaustivamente contada e recontada pelos profissionais das áreas da educação, do teatro, das artes visuais - somente para citar algumas - no Brasil, desde 2002, data da publicação da primeira edição brasileira do livro de Rancière, a aventura intelectual vivida, em 1818, por Joseph Jacotot nasce no acaso de uma experiência entre homens e um livro, orientada pela vontade de se aprender uma nova língua. Outro homem do entre, Jacotot, mestre ignorante, apesar de se reconhecer um explicador até o início dessa aventura, tem, em sua biografia, convívios com emancipadores e gestos emancipatórios. Nascido em 1770, na França, neto de um carpinteiro e filho de um açougueiro que depois cuidou das contas de seu pai, o avô carpinteiro, Jacotot viraria professor de retórica. Em 1792, o professor de retórica escuta ecoar o apelo às armas, em meio à Revolução Francesa, e seus companheiros o elegem capitão da artilharia. Em 1793, Jacotot, professor de retórica, instrui química a operários. Esses operários eram enviados a todos os cantos do território francês para aplicar esses conhecimentos de química. Nesse percurso, o professor de retórica, também latinista e instrutor de química, conhece o principal químico de sua época. Na casa desse químico, conhece também o filho de um camponês que havia se ensinado química a si mesmo, escondido de seu patrão. O filho do camponês aprende sozinho química perto do grande químico da época. Muitas outros feitos se dão, debaixo dos olhos de Jacotot, ligados aos temas da aprendizagem e do ensino, e ele mesmo também aprende matemática e hebraico. "A urgência da Revolução fazia nascer capacidades inéditas. A urgência obrigava a queimar etapas da progressão explicativa" (Rancière, 2007, p.19). Jacotot relata, desse modo, sua experiência do acaso:

Encontrava-me, como se sabe, como professor em uma universidade estrangeira após uma sucessão de coisas extraordinárias. Nenhum dos primeiros alunos que se apresentaram a mim para aprender o francês compreendia essa língua; havia, dentre eles, quem não entendia o que eu dizia. Pus em suas mãos um Telêmaco em uma velha tradução em sua língua materna. Um companheiro, que servia de intérprete, disse a eles que o professor lhes pedia que aprendessem o texto em francês, convidando-os a se ajudarem com a tradução para o compreenderem. Esses jovens aprenderam eficazmente a metade desse primeiro livro, até essas palavras: "havia partido de Ítaca". Então, fiz-lhe dizer que repetissem sem parar o 
que sabiam e que se conformassem em ler o resto para contá-lo. Depois disse-lhes que escrevessem o que pensavam de tudo isso. Eu havia sido explicador toda a minha vida, por conseguinte, acreditava, como meus colegas, que as explicações, e sobretudo as minhas explicações, eram necessárias: qual foi minha surpresa quando vi que se podia prescindir delas! O fato estava debaixo dos meus olhos, não podia pô-lo em dúvida. Tomei meu partido e decidi não explicar nada, para assegurar-me sobre até onde o aluno podia ir desse modo, sem explicações. Aconteceu que os alunos localizavam a ortografia e seguiam as regras da gramática à medida que os vinte e quatro livros tornavam-se familiares a eles, por meio da repetição. Mas um resultado que me surpreendeu além de tudo foi ver alguns pequenos estrangeiros escrevendo como escritores franceses, e, por conseguinte, melhor que meus colegas professores explicadores (Jacotot, 2008, p.290).

Em Jacotot, a ignorância é tratada, fundamentalmente, em duas instâncias distintas. Em seu aforismo mais conhecido, "todos os homens têm uma inteligência igual", Jacotot propõe que o mestre ignore a diferença entre sua inteligência e a do aluno, e, assim, nomeia-o mestre ignorante. Na outra instância, Jacotot propõe que se ensine o que se ignora. Em seu método, pais analfabetos ensinaram filhos a ler e ele mesmo, mestre ignorante, ensinou pintura e piano sem saber. Ao inverter o sentido da dissociação entre saber e ignorar, o mestre ignorante não exerce nenhuma relação hierárquica entre as inteligências sua e do aluno. Ao contrário, o mestre ignorante é somente uma vontade que orienta que o ignorante faça o caminho, ou seja que ele faça uso da capacidade "que todo homem já demonstrou ao alcançar, sem mestre, a mais difícil das aprendizagens: a dessa língua estrangeira que é, para toda criança que vem ao mundo, a língua denominada materna" (Rancière, s/d). ${ }^{10}$

Pensarmos a ignorância, nessa composição que vimos estabelecendo, significa tentar pensar relações de encontro entre textos e ações sem a presença do expert, e também insistir em alguma distância do modo interpretativo de nos relacionarmos com textos. Por isso, elegemos pensar a relação de pessoas com textos junto com Joseph Jacotot e Jacques Rancière. Saltemos de volta ao presente a fim de seguir pensando em alguns ecos pedagogizantes na cena contemporânea, adentrando em conexões feitas por Rancière entre temas de $O$ mestre ignorante e questões relativas ao espectador e à cena:

O que o aluno deve aprender é aquilo que o mestre o faz aprender. O que o espectador deve ver é aquilo que o diretor o faz ver. O que aquele deve sentir é a energia que este lhe comunica. A essa identidade de causa e efeito, que está no cerne da lógica embrutecedora, a emancipação opõe sua dissociação. E o sentido do paradoxo do mestre ignorante: o aluno aprende do mestre algo que o mestre não sabe. Aprende como efeito da habilidade que o obriga a buscar e comprova essa busca. Mas não aprende o saber do mestre (Rancière, 2008, p.20).

\title{
Espaços de intrusão
}

\author{
Em 2004, a convite do performer sueco Marten Spaknberg, o filósofo Jacques
}

10 "[...] que tout homme a démontrée en réussissant sans maître le plus difficile des apprentissages: celui de cette langue étrangère qu'est pour tout enfant venant au monde la langue dite maternelle". (Tradução nossa). 
Rancière escreve a conferência $O$ espectador emancipado, com o objetivo de, a partir das ideias desenvolvidas em $O$ mestre ignorante: cinco lições sobre a emancipação intelectual, "introduzir a reflexão a um grupo de artistas dedicado ao espectador" (Rancière, 2012, p. 7). Em conexão com a abrangência temática presente no livro homônimo e especificamente em seu texto de abertura, precisamos citar um longo trecho:

\begin{abstract}
Dir-se-á que o artista, ao contrário [Rancière aqui o compara ao mestre], não quer instruir o espectador. Hoje ele se defende de usar a cena para impor uma lição ou transmitir uma mensagem. Quer apenas produzir uma forma de consciência, uma intensidade de sentimento, uma energia para a ação. Mas supõe sempre que o que será percebido, sentido, compreendido é o que ele pôs em sua dramaturgia ou sua performance. Pressupõe sempre a identidade entre causa e efeito. Essa igualdade suposta entre causa e efeito baseia-se num princípio desigualitário: baseia-se no privilégio que o mestre se outorga, no conhecimento da "boa" distância e do meio de eliminá-la. Mas isso é confundir duas distâncias bem diferentes. Existe a distância entre o artista e o espectador, mas existe também a distância inerente também à própria performance, uma vez que, como espetáculo, ela se mantém como coisa autônoma, entre a ideia do artista e a sensação ou a compreensão do espectador. Na lógica da emancipação há sempre entre o mestre ignorante e o aprendiz emancipado uma terceira coisa - um livro ou qualquer outro escrito - estranha a ambos e à qual eles podem recorrer para comprovar juntos $\mathrm{o}$ que o aluno viu, o que disse e o que pensa a respeito. A mesma coisa acontece com a performance. Ela não é a transmissão de saber ou do sopro do artista ao espectador. É essa terceira coisa de que nenhum deles é proprietário, cujo sentido nenhum deles possui, que se mantém entre eles, afastando qualquer transmissão fiel, qualquer identidade entre causa e efeito (Rancière, 2012, pp.18-19).
\end{abstract}

A partir daqui, já se pode começar a pensar em aspectos presentes desde nossas origens teatrais (e educacionais, ainda que realizadas por meio da cena) relacionados ao modo de se aproximar de textos, de fazer agir cenicamente esses textos com metas pedagógicas. A identidade entre causa e efeito, reconhecida por Rancière na cena contemporânea, pode e deve também ser pensada a partir de conexões com o fazer teatral, em nossa história, que fez (e faz) o ator agir como instrutor, a escritura cênica agir como texto de livro didático a ser interpretado corretamente pelos alunos, o debate com artistas agir como gesto de mestre explicador, e a tal ânsia pela autonomia do espectador transformar-se em sinônimo de embrutecimento, ao supor sempre um saber outro e superior a ser atingido, equiparado. Resta seguirmos perguntando como essa "terceira coisa", esse "algo em comum", a ser posto entre cena e público, entre artistas e espectadores, entre professor e aluno, pode ser escutado, operado, obrado - diríamos, preferencialmente, desobrado -, manuseado, sem que nossos corpos não caiam da cilada do arraigado gesto educador? Propomos pensar no silêncio entre nós, na possibilidade de sustentarmos a permanência na espera, ao emudecermos, ainda que por pouco tempo, os monólogos do pensamento - inclusive aqueles que falam ainda que sem som vocal -, para que algum dissenso possa se dar:

O que há são simples cenas de dissenso, capazes de sobrevir em qualquer lugar, a qualquer momento. Dissenso quer dizer uma organização do sensível na qual não há realidade oculta sob as aparências, nem regime único de apresentação e interpretação do dado que imponha a todos a sua evidência. É que toda situação é passível de ser fendida no interior, reconfigurada sob outro regime de percepção e significação. Reconfigurar a paisagem do perceptível e do pensável é modificar 
o território do possível e a distribuição das capacidades e incapacidades. [...] É nisso que consiste o processo de subjetivação política: na ação de capacidades não contadas que vêm fender a unidade do dado e a evidência do visível para desenhar uma nova topografia do possível (Rancière, 2012, p.48).

Ensaiemos uma fenda, repondo a configuração desse espaço que vimos esboçando até aqui. Pusemos, lado a lado, algumas ideias: o gesto ensaístico inaugural de Michel de Montaigne - sublinhando o delineamento de seu espaço de leitura, de escrita, de texto, e as ideias que opõe à leitura e à escrita como interpretação de textos; uma origem híbrida entre cena e aula em nossa história brasileira; uma breve ideia sobre o repouso, a aproximação de textos como cópia, aliando-nos a Benjamin; uma breve ideia sobre a deriva, os gestos de desvio e de saída dos textos, que nos acontecem frequentemente a todos os que lemos. Entre Joseph Jacotot e Jacques Rancière, abrimos, ainda, algum pensamento sobre o assunto da impossibilidade identitária entre artista, obra e espectador, assunto este dado desde o tema do compreender entre a adivinhação, a tradução e a contra-tradução, até a proposta de Rancière por uma reconfiguração das capacidades e das incapacidades num dissenso possivel. Queremos, com esse paralelismo entre ideias, seguir pensando nossas relações com textos entre cena e aula, rascunhando a delimitação de um espaço.

Meditamos acerca do encontro ao redor de textos como espaço para solidão e vínculo, que sublinhe a existência do entre desde sua forma de acontecimento, aquele entrecruzamento (Nancy, 2013) que mantém visível a distância e a separação, afirmando-as. Daqui recorremos a Fernand Deligny, que amplia o campo para pensarmos o tema:

Uma jangada, sabem como é feita: há uns troncos de madeira amarrados entre si de forma bastante solta, de modo que, quando as montanhas de água caem por cima deles, a água passa através dos troncos afastados. É por isso que uma jangada não é um esquife. Dito de outro modo: nós não retemos as perguntas. Nossa liberdade relativa procede dessa estrutura rudimentar. E creio que esses que a conceberam refiro-me à jangada - fizeram o melhor que puderam, pois de fato não estavam em condições de construir uma embarcação. Quando chovem as perguntas, nós não cerramos as fileiras - não juntamos os troncos - para constituir uma plataforma bem preparada. Muito pelo contrário. Do projeto, somente retemos isso que nos vincula. Podem ver, assim, a importância primordial dos vínculos e do modo de amarração, e da distância mesma que os troncos podem ter entre si. $\mathrm{O}$ vínculo tem que ser bastante solto e que não se solte (Deligny, 2009, p.43).

O vínculo manteria esse entre como tal? No entre que pretendemos delinear, espaço de encontro, nem aula nem cena, porém suspenso entre cena e aula, o que se quer é ignorar o saber especialista. Na aliança com Jacotot e Rancière, queremos pensar o texto entre pessoas como um lugar no qual se entrecruza a cabeça para baixo, que lê, que repousa, e a cabeça para cima, que lê palavras em vigas inexistentes, no seu próprio monólogo interior, aquele que nunca cessa. Aceitar o fio da errância, da caminhada que ao buscar copiar, desvia. Mas só desvia porque busca copiar (Benjamin, 1987). Não se trata de uma deriva por si, de sublinhar uma voz que precisa dizer, que precisa soar. Trata-se, ao contrário, de dar voz ao que já se passa ali, in loco. 


\section{Impossibilidades do comum, entre agir e não-agir}

Em nossa insistência para pensar ideias, movimentos, impulsos acerca da copresença entre textos e pessoas, e a pensar a ausência de vozes especialistas nesse encontro, tem-nos sido perturbadora a presença daquele que poderia ser nomeado como um conceito: o desobramento ou a inoperatividade - as traduções divergem.

$\mathrm{Na}$ edição de 2007 das Conferências Internacionais Serralves sobre o tema Política, o filósofo Giorgio Agamben, na conferência Arte, inoperatividade, política, repõe o conceito desobramento (traduzido como inoperatividade), recorrente em sua obra, com o fim de tratar da atividade de desativar. Em conexão com Espinosa, trata do desobrar como uma possibilidade dos homens para contemplar o seu poder de agir, "a vida que contempla seu próprio poder, torna-se inoperativa em todas as suas operações" (Agamben, 2007, p.48). Aristóteles, também citado por Agamben, ao tratar do tema da "felicidade como objeto último da ciência política" (Agamben, 2007, p.46), na Ética a Nicômaco, evoca a ideia de uma "possível inoperatividade da espécie humana" (Agamben, 2007, p.47). Em Aristóteles lemos:

En todos los que realizan alguna obra o tienen alguna actividad lo bueno parece estar relacionado con el obrar, y así, en el hombre, aparentan serlo, propiamente, las funciones que le son inherentes. ¿O sólo habrá algunas actividades propias del carpintero y del zapatero, pero ninguna de un hombre, si éste mismo no tuviera ningún oficio? ¿O sucederá acaso que, así como hay una función propia del ojo, de la mano, del pie, y en general de todos los miembros, también podría seguirse de todo eso en el hombre alguna función diferente y peculiar? Y cuál sería esta? En todo caso el vivir parece común a todas las plantas y aqui buscamos lo inherente (Aristóteles, 2009, p.35). 11

Da conferência de Agamben, tomamos para nossa composição pensar um possível uso do corpo desobrado, nesse espaço de encontro e relação com textos e ações deles derivadas. Propomos traçar um paralelo com o que seria o princípio da geração de algum corpo ensaístico, pensado entre cena e aula, na percepção daquilo que não necessariamente possa almejar um encontro de iguais, mas, ao contrário, a percepção daquilo que nos separa. Das práticas que a cena pode levar para a aula, por entre um vozerio de alguns autores ${ }^{12}$, poderíamos escutar um sussurro, de uma voz sem dono, a dizer: apesar de esse encontro ser teatro, de essa forma estar coberta pela ideia absurda de assembleia, ou de comunidade, nós não estamos juntos, aliás, nós nunca estivemos juntos, e eu sou muito diferente de você e sou também muito diferente de mim mesmo. A comunidade nunca existiu (Nancy, 1986). "O paralogismo dos filósofos consiste em imaginar um povo de homens. Mas esta é uma expressão contraditória, um ser impossível." (Rancière, 2007, p.129).

O sentido de partilha está coberto tanto por aquilo que pode oferecer algo em comum entre nós (um livro, por exemplo), quanto, justamente, pelo fato de a presen-

11 Optamos pela edição espanhola.

12 Guénoun, 1998; Nancy, 1986, Pelbart, 2003; e ditos orais entre o Mali, o Burkina Faso e o Brasil (Jardim, 2011; 2009). 
ça desse algo comum ser o que delimita aquilo que nos separa em peles, vozes ou órgãos diversos, diferentes, in-comungáveis.

A arte não é uma atividade humana de ordem estética, que pode, eventualmente e
em determinadas circunstâncias, adquirir também um significado político. A arte
é em si própria constitutivamente política, por ser uma operação que torna inope-
rativo e que contempla os sentidos e os gestos habituais dos homens e que, desta
forma, os abre a um novo possível uso. Por isso, a arte aproxima-se da política
e da filosofia até quase confundir-se com elas. Aquilo que a poesia cumpre em
relação ao poder de dizer e a arte em relação aos sentidos, a política e a filosofia
têm de cumprir em relação ao poder de agir. Tornando inoperativas as opera-
ções biológicas, econômicas e sociais, elas mostram o que pode o corpo humano,
abrem-no a um novo, possível uso (Agamben, 2007, p.49).

Pensar aula e cena como encontro entre ensaístas na relação com textos e gestos possíveis em torno deles, a partir da ausência dos saberes especialistas, tem-nos feito meditar sobre as incapacidades extremas e alguns lugares insignificantes nos quais os corpos não podem agir. Essas meditações foram intensificadas ao sermos flechados por Fernand Deligny, educador, escritor e cineasta francês, já citado no presente texto: sua ação, sua escrita, seu traçado cinematográfico, seu pensamento. Rastros de contatos com seus temas podem nos amparar e, quem sabe, radicalizar a potência do tema desobramento para outros mais fundos buracos.

Vimos pensando um encontro, nesse espaço entre aula e cena, que transita entre obra e desobra, entre operar e inoperar, com algo tão fixo como um texto - que é também sempre obra que já foi operação. Esse encontro tem oralidade, tem dizer e tem escrita, lida e traçada. Diante ou sob tanta intensificação da ação - afinal tratamos de aula e de cena, ambiências do agir -, tem-nos sido cara a ideia de pensar os corpos inativos, derrubados, indigentes, num fio quase urgente que precisa opor os excessos do agir à radicalidade da não palavra, do silêncio abissal. Talvez por estar à superfície do que vimos pensando como encontro a afirmação de algum não saber, de qualquer saber, do resto do que se sabe, daquilo que vem depois do pensamento, depois da ação, da hiper ação, e que talvez esteja justamente em um bocejo, em um descuido, num descaso e, por que não dizer, até mesmo fora do espaço do tal encontro. Inoperar a sua própria atividade, contemplar, mirar desde o silêncio, seu poder, e seu poder de agir.

Buscando evitar que nossa composição ressoe a algum humanismo, ainda que às avessas, e por certa aliança com uma possível intensificação do tema desobramento, elegemos encerrar este ensaio mirando um novo começo. Perto dos olhos de Fernand Deligny, podemos nos desviar para um horizonte talvez ainda mais estranho ao espaço que vimos compondo. Traduzimos a seguir um trecho de seu Prefácio ao livro Les détours de l'agir ou le moindre geste (Os desvios do agir ou o menor gesto). Optamos por manter uma forma aproximada do texto e de seus espaços, conforme publicados nas Oeuvres:

"Eu estou convencido de que o humanismo porta em si mesmo os fascismos, totalitarismos, e todos os desastres de civilização, assim como disse que o 
capitalismo portava a guerra, da mesma maneira que a nuvem negra porta a trovoada.

Os homens se fizeram uma imagem deles mesmos que se reproduz com matizes.

Para o que tenho pensado, é essa imagem - ela mesma, adquirida, aprendida, integrada, inveterada - que eclipsa o resto.

É esse resto que, escrevendo, eu tento evocar.

É esse resto - considerado como um resíduo, uma sobrevivência que vai se atrofiando - que eu considero como sendo um esboço disso que poderia ser o humano se, desde sempre, a crença naquilo que o homem se imagina ser não tivesse sido suplantada por essa outra coisa que aparece quando uma criança se revela autista, conforme se costuma dizer.

Essa posição não me caiu do céu.

Como todos aqueles que têm a minha idade, foi-me preciso viver as carências e os exageros dos "ismos" portadores de esperança. Depois, foi-me preciso perceber que meus vizinhos próximos - autistas, eu já disse - , refratários à domesticação simbólica, desprovidos dessa imagem do homenzinho que nos incumbem, eram, na verdade, bem estranhos.

Então escrever, descrever? Mas em que língua devem falar, esses que não falam nenhuma?

\section{$[\ldots]$}

Que o agir seja desprovido de intenção, é exatamente isso que quero dizer.

No entanto, o agir existe, belo e bem, humano, para não duvidar dele, e não como resíduo de alguma inaptidão, mas esboço liminar daquilo que a imagem herdada que cada um faz, para si, do homem, se esquiva desde sempre" (Deligny, 2007, pp. 1249-1250). ${ }^{13}$

\footnotetext{
13 "Je suis, pour ma part, persuadé que l'humanisme porte en lui-même les fascismes, totalitarismes, et tous les désastres de civilisation, tout comme on a dit que le capitalisme portait la guerre, de la même manière que la nuée porte l'orage. Les hommes se sont fait une image d'eux-mêmes qui se reproduit avec des nuances. Pour ce que j'en pense, c'est cette image même acquise, apprise, intégrée, invétérée qui éclipse le reste. C'est ce reste, qu'écrivant, je tente d'évoquer. C'est ce reste, considéré comme un résidu, une survivance qui va s'atrophiant, que se considère comme étant l'ébauche de ce qu'il pourrait en être de l'humain si, depuis toujours la croyance en ce que l'homme imagine être $n$ était venue supplanter, se supposer à cet autre chose qui apparaît lorsqu'un enfant s'avère, comme on dit, autiste. Cette position ne m'est pas tombée du ciel. II m'a fallu vivre, comme tous ceux qui ont mon âge, les carences et les outrances des « ismes » porteurs d'espérance. Et puis il a fallu m'apercevoir que mes voisins proches, autistes je l'ai dit, réfractaires à la domestication symbolique, démunis de cette image du bonhomme qui nous incombe, étaient, à vrai dire, bien étranges. Alors écrire, décrire? Mais en quelle langue parler ceux qui n'en parlent aucune? [...] Que l'agir soit dépourvu d'intention, c'est bien ce que je veux dire. Et pourtant, l'agir existe bel et bien, humain à n'en pas douter, et non pas résidu de quelque inaptitude, mais ébauche liminaire de ce que l'image héritée que chacun se fait de l'homme élude depuis toujours." (Tradução nossa)
} 


\section{Referências}

ADORNO, Theodor W. O ensaio como forma. In: Notas de literatura I. São Paulo: Duas Cidades e Ed. 34, 2003, p. 15-45.

AGAMBEN, Giorgio. Arte, inoperatividade, política. In: Crítica do contemporâ neo. Conferências internacionais Serralves. Porto, Fundação Serralves, 2008.

ARISTÓTELES. Ética a Nicómaco. Madrid: Editorial Tecnos, 2009.

AUERBACH, Erich. O escritor Montaigne. In: Ensaios de literatura ocidental: filo logia e crítica. São Paulo, Duas Cidades e Ed.34, 2007, p. 145-166.

BENJAMIN, Walter. Rua de mão única. Obras escolhidas II. São Paulo: Brasilien se, 1987.

BROOK, Peter. O diabo é o aborrecimento. Conversas sobre teatro. Porto: Edi ções Asa, 1993.

DELIGNY, Fernand. Le croire et le craindre. In: Oeuvres. Paris: Éditions L'Ara chnéen, 2007, p. 1084-1209.

Les détours de l'agir ou le moindre geste. In: L'Arachneén et autres tex tes. Paris: Éditions L'Arachnéen, 2008, p. 1247-1347.

Permitir. Trazar. Ver. Barcelona: Museu d'Art Contemporani de Barcelo na, 2009.

DERRIDA, Jacques. assinatura acontecimento contexto. In: Margens da filosofia. Campinas: Papirus, 1991, p. 349-358.

GUÉNOUN, Denis. L'Éxhibition des mots et autres idées du théâtre et de la phi losophie. Paris: Circé, 1998.

HANSEN, João Adolfo. Anchieta: poesia em tupi e produção da alma. In: CARA, Salete de Almeida e JÚNIOR, Benjamin Abdala (Org.). Moderno de nascença: $f$ igurações críticas do Brasil. São Paulo: Boitempo Editorial, 2006, p. 11-26.

JACOTOT, Joseph. Enseñanza universal. Lengua materna. Buenos Aires: Cactus, 2008. http://joseph-jacotot.over-blog.com

JARDIM, Juliana. vestígios do dizer de uma escuta (repouso e deriva na palavra). Tese de doutorado. São Paulo: CAC-ECA-USP, 2009. 
Pensar a desdramatização a partir de uma aliança (e alguns risos) com

Sotigui Kouyaté: um texto-fala em sete fragmentos. In: aParte XXI, n.4. São Pau lo: Tusp-USP, 2011, p. 48-61.

LEGROS, A. Essais sur poutres. Peintures et inscriptions chez Montaigne. Paris: Klincksieck, 2000.

Catalogue tour/Dépliant de Mr Alain Legros. Saint-Michel de Montaigne: Chateau-Montaigne/Tour historique, s/d.

MAGNIEN, Michel e MAGNIEN-SIMONIN, Catherine. Un home, un livre. In: MON TAIGNE, Michel de. Les essais. Paris: Éditions Gallimard, 2007, p. IX-XXXI.

MONTAIGNE, , Michel de. Ensaios, vols. 1, 2 e 3. São Paulo: Abril Cultural, 1984. Les essais. Paris: Éditions Gallimard, 2007.

NANCY , Jean-Luc. Etre singulier pluriel. Paris: Galilée, 2013. La comunidad inoperante. Santiago: Editorial LOM, 1986.

PELBART, Peter Pál. Da clausura do fora ao fora da clausura - loucura e desra zão. São Paulo: Editora Brasiliense, 1989.

Vida capital: ensaios de biopolítica. São Paulo: Ed. Iluminuras, 2003.

PRADO, Décio de Almeida. As raízes do teatro brasileiro. In: FARIA, João Roberto (Org.). História do teatro brasileiro, vol. 1 e 2. São Paulo: Perspectiva-Edições SESCSP, 2013, p. 21-66.

RANCIÈRE, Jacques. O espectador emancipado. São Paulo: Editora WMF Mar tins Fontes, 2012.

O mestre ignorante: cinco lições sobre a emancipação intelectual. Belo Horizonte, Autêntica, 2008.

http://www.multitudes.net/Sur-Le-maitre-ignorant/In: Multitudes, re vue politique, artistique, philosophique, Paris: s/d.

STAROBISNKI, Jean. É possível definir o ensaio? In: Serrote, n. 10. São Paulo: Instituto Moreira Salles, março 2012, p. 43-61.

ZWEIG, Stefan. Montaigne. Paris: Praisses Universitaires de France, 1982.

Recebido em: 08/09/2015

Aprovado em: 04/07/2016 